УДК 37.015.31-053.4

DOI: $\underline{10.35619 / \text { iiu.v1i14.405 }}$

Березовська Людмила

доктор педагогічних наук, доцент, завідувач кафедри теорії і методики дошкільної освіти Д3 «Південноукраїнського національного педагогічного університету імені К. Д. Ушинського», м. Одеса. Україна ORCID: 0000-0002-3032-7261 e-mail: lydunya@gmail.com

\title{
НАВЧАННЯ ТВОРЧІСТЮ В ПЕДАГОГІЧНІЙ СПАДЩИНІ ВАСИЛЯ СУХОМЛИНСЬКОГО: РОЗКРИТТЯ ТВОРЧОГО ПОТЕНЦАЛУ ОСОБИСТОСТІ ДИТИНИ
}

\begin{abstract}
Анотація. У статті здійснено аналіз поняття «творчість»; проаналізовано погляди Василя Сухомлинського щодо необхідності розвитку творчих здібностей дітей засобами художнього слова. Розглянуто особливості педагогічної діяльності $\mathrm{B}$. О. Сухомлинського, які $\epsilon$ актуальними і можуть бути впроваджені в сучасних закладах освіти. Особливістю творчої діяльності вихователів закладів дошкільної освіти $\epsilon$ особистий приклад педагога, рівень розвитку його творчої активності, вміння бачити і відчувати красу рідного слова. Результати проведеного дослідження засвідчили, що вихователі не приділяють належної уваги розвитку творчих здібностей дітей, у них самих недостатньо сформована потреба і готовність до творчості в професійній діяльності. Характерною особливістю педагогічної творчості $є$ співтворчість між педагогом та вихованцями, покликана стимулювати в особистості дитини творчі здібності, здобувати знання та вміння, завдяки яким створюється оригінальний, індивідуальний продукт, що вирізняється багатством емоційно-образного мислення, творчим задумом, яскравим сюжетом, специфічним словотворенням. Ефективною формою розвитку творчого мовлення $є$ складання розповідей, казок, оповідань. Ознаками творчої діяльності є: нетрадиційне, оригінальне мислення; нетиповий спосіб вирішення проблемних ситуацій; творчі можливості дитини.

Створюючи нові розповіді, казки, оповідання, дитина входить у світ фантастичної дійсності, вчиться відчувати красу рідного слова, бути неповторною та оригінальною у своїх рішеннях.
\end{abstract}

Ключові слова. Василь Сухомлинський, педагогічна спадщина, творчість, формування творчої особистості, діти дошкільного віку, казка.

Постановка проблеми. Сучасний стан розвитку дошкільної освіти спрямований на гармонійний, всебічний розвиток дитини, стимулювання іiї творчої активності, дитячої самобутності. Формування такої особистості 


\section{Інноватика у вихованні. Випуск 14. 2021.}

значною мірою залежить від особистості педагога, який допомагає дитині розкрити іiі внутрішній світ, природні задатки, творчі здібності. Особливістю педагогічної діяльності педагога $\epsilon$ те, як він втілює свої професійні знання в роботу з дітьми, чи продукує нові ідеї та форми організації освітньо-виховного процесу, що сприяють вихованню творчої особистості дитини, ії потенційних можливостей. На становлення творчого потенціалу особистості наголошено і в Базовому компоненті дошкільної освіти (2021р.), законах України «Про освіту» (2017 р.), «Про дошкільну освіту» (2001р.), Національній стратегії розвитку освіти України (20122021 р.) та інших законодавчих документах. 3 огляду на це, модернізація системи дошкільної освіти спрямована на розкриття творчого потенціалу особистості дитини, ії задатків, нахилів та здібностей.

Аналіз останніх досліджень 3 проблеми. Проблеми творчого розвитку особистості була предметом дослідження українських учених. Зокрема, формуванню творчої особистості присвячено дослідження І. Беха, Л. Виготського, Д. Ельконіна, О. Кононко, Г. Костюка, В. Роменця та ін. Мовленнєво-творча діяльність дітей дошкільного віку була предметом вивчення А. Богуш, Л. Березовської, Н. Водолаги, Н. Гавриш, К. Крутій, Н. Луцан та ін. Водночас у педагогічному вимірі розвитку дитячої творчості на особливу увагу заслуговує наукова спадщина Василя Сухомлинського. Проблема творчості, яку педагог називав «педагогічною цілиною» (Сухомлинський, 1977, с 565), була особливо значуща у науковому доробку вченого.

Мета статті - опрацювати та здійснити аналіз педагогічної спадщини В. Сухомлинського щодо розвитку творчої особистості дитини засобами казки.

Виклад основного матеріалу дослідження. Педагогічна спадщина В. О. Сухомлинського багатогранна і різноманітна. Аналізуючи науковопедагогічні праці видатного педагога, знаходимо відповіді на різнобічні питання, пов'язані із залученням дітей до краси рідного слова, мистецтва, морально-духовного та художньо-естетичного сприйняття довколишнього світу. Пріоритетним для вченого було виховання дитини на засадах таких загальнолюдських цінностей, як щирість, чесність, порядність, справедливість, бажання допомогти іншим. Завдання педагога, писав Василь Сухомлинський, «виховати справжню людяність, високоморальні, гуманні вчинки, які свідчать про повагу до людської гідності» (Сухомлинський, 1977, с. 295). Від вихователя залежить, яким бачить світ дитина, що ії хвилює, дивує, турбує, зворушує (Сухомлинський, 1977, с. 434).

Вагоме місце у педагогічній спадщині Василя Сухомлинського відведено проблемі розвитку творчої особистості. Саме на розвиток творчої особистості спрямовувався освітньо-виховний процес у Павлиській школі. Василь Олександрович дбав про те, аби пробудити у дітей «жадобу знань» (Сухомлинський, 1977, с. 411), «радість від успіху в інтелектуальній праці», (Сухомлинський, 1976, с. 253), яскраві естетичні 


\section{Інноватика у вихованні. Випуск 14. 2021.}

почуття, благородство духовного та емоційного сприйняття довколишнього світу, «стан духовного піднесення, викликаного радісним спілкуванням із книжкою» (Сухомлинський, 1977, с. 421), вміння «творити словом» (Сухомлинський, 1976, с. 507). Педагог писав, що «творчість - це діяльність, у яку людина вкладає частинку своєї душі» Сухомлинський, 1976, с. 507). Як директор школи, вмілий педагог зумів довести, що школа це не лише місце, де діти здобувають знання, а осередок духовноморального та творчого розвитку дитини, в якому відбувається їі становлення, формується багатогранна, неповторна особистість. У «Школі радості» педагог дбав про те, щоб діти почувалися природно, були самі собою, виявляли свої думки, почуття, отримували задоволення від навчання. Заняття проводилися не у стінах школи, а на лоні природи, під блакитним небом. У розділі «Школа під блакитним небом» (Сухомлинський, 1877, с. 32) педагог зворушливо описує, як відбувався процес навчання: «Ми вийшли із села, розташувалися на високому кургані. Перед нами відкрився чудовий краєвид на широкий, немов палаючий під сонцем луг, на стрункі тополі, кургани, що даленіли на обрії. Ми прийшли до джерел думки й слова» (Сухомлинський, 1977, с. 32). Василь Сухомлинський - майстер художнього слова, тому й недивно, що діти слухали розповіді педагога, затамувавши подих і мимоволі, ніби самі ставали учасниками тих подій, про які оповідав великий Учитель. Дитяча творчість започатковується словом. Проте тільки творчий педагог може виховати творчу особистість. 3 цього приводу педагог слушно зауважував, що «слово в одного вчителя є могутнім засобом виховання, а в другого пекельна мука для вихованців». На переконання педагога, «велике лихо в тому, що вихователь не вміє вибирати із скарбниці мови саме ті слова, які необхідні» (Сухомлинський, 1977, с. 507), аби достукатися до серця дитини, розкрити їі внутрішній світ.

Результати проведеного нами дослідження з теми «Розвиток творчого мовлення дітей старшого дошкільного віку в процесі складання казкових сюжетів» засвідчили, що вихователі ЗДО не приділяють належної уваги розвитку творчих здібностей дітей, не цілком усвідомлюють роль творчої діяльності у формуванні особистості дитини. До того ж у них самих недостатньо сформована потреба і готовність до творчості; у професійній діяльності віддають перевагу традиційним формам та методам роботи 3 дітьми, не проявляють ініціативи та винахідливості у впровадженні нових ідей та підходів до організації освітнього процесу, авторських розроблень конспектів занять, методик роботи з дітьми, які б сприяли розвитку словотворення та словесної творчості, дитячої фантазії та уяви, мовленнєво творчої діяльності.

У словотворенні бере участь людина, яка має свої індивідуальні особливості, мовні і мовленнєві здібності, і втілює їх у створених нею словах. Відомий український лінгвіст Л. Булаховський писав «нехай вигадані якимись художниками нові слова лишаються назавжди тільки їхніми словами, нехай вони не надходять до активного фонду загальної 


\section{Інноватика у вихованні. Випуск 14. 2021.}

мови, - але там, де їх ужито, вони живуть своїм повним художньоестетичним життям, вони $є$ збагаченням мови, виявом образності та емоційності i, якщо вони подобаються хоча б якомусь колу читачів, тим самим виправдовують своє народження і своє існування» (Булаховський, 1947, с.136).

Творчі здобутки людини в будь-якій діяльності зумовлені певним рівнем іiі компетентності, розвитком емоційно-чуттєвої сфери. Творчість пов'язана із самостійно народженим оригінальним задумом, добором оригінальних засобів його реалізації та створенням нового унікального творчого продукту (Березовська, 2004, с. 40).

У словникових виданнях поняття «творчість» характеризується як діяльність людини, спрямована на створення духовних і матеріальних цінностей; діяльність, пройнята елементами нового, спрямована на вдосконалення і збагачення розвитку (Яременко, Сліпушко, 2006). Творчість - продуктивна людська діяльність, здатна породжувати якісно нові матеріальні і духовні цінності суспільного значення (Гончаренко, 1997, с. 326).

Психологи (Л. Виготський, В. Моляко, Я. Пономарьов, В. Роменець та ін.) вважають, якщо можливості людини перебільшують ії діяльність, тоді ця різниця між потенційним і реальним реалізується у творчості.

У науково-педагогічних колах поняття «творчість» визначається як: «засіб реалізації творчих можливостей особистості» (Сисоєва, 2006, с. 94); «містить елементи новизни, пов'язані не стільки 3 продукуванням прийомів освітньо-виховної діяльності, скільки з їх модернізацією» (Гузій, 2015, с. 133); «це діяльність, у результаті якої створюється щось принципово нове, оригінальне, що тією чи іншою мірою відбиває індивідуальні нахили, здібності і досвід учня» (Ямницький, 1993, с. 11); «це процес створення, відкриття чогось нового, раніше для цього конкретного суб’єкта невідомого» (Моляко, 1985, с. 11).

Аналогічну думку знаходимо i y Василя Сухомлинського, який переконував, що «творчість започатковується там, де інтелектуальні й естетичні багатства, засвоєні, здобуті раніше, стають засобом пізнання, освоєння, перетворення світу» (Сухомлинський, 1977, с. 566).

Отже, визначальними рисами творчості $\epsilon$ новизна, оригінальність задуму, нестандартність у рішеннях, вихід за межі відомого, встановлення нових зв'язків та закономірностей.

Досліджуючи заявлену тему мали за дороговказ те, що творчість вихователя закладу дошкільної освіти - це вихід за межі рольових настанов, яка проявляється у нестандартних підходах до організації освітнього процесу, розробленні та впровадженні нових форм і методів роботи, педагогічній імпровізації, що сприяє ефективності процесу навчання.

Характерною особливістю педагогічної творчості є те, що це завжди співтворчість між педагогом та вихованцями, покликана «пробудити»в особистості дитини творчі здібності, знання та вміння, завдяки яким 


\section{Інноватика у вихованні. Випуск 14. 2021.}

створюється оригінальний, індивідуальний продукт, що вирізняється багатством емоційно-образного мислення, творчим задумом, яскравим сюжетом, специфічним словотворенням. Природним для дитини у процесі мовленнєвої творчості є момент естетичного милування результатом своєї творчості, що зі свого боку, передбачає володіння нормою і технікою побудови різного типу висловлювань, а також високий рівень художньоестетичного сприймання і творчої уяви (Гавриш, 2001 с. 80-82). В умовах організованого навчання вихователька планує тему, мету, освітні завдання. Діти зацікавлюються пропозицією педагога «Давайте поміркуємо...» і завдяки його майстерності та вмінню донести свою думку включаються у творчий процес. В ініціативній творчості дитина вільна. Проте звертається до творчої діяльності лише тоді, коли насправді відчуває потребу творити. Тому для вихователя ЗДО важливо створити такі умови, щоб дитина відчула внутрішню потребу творчого самовираження, отримуючи задоволення від уміння бачити світ у казкових образах. «Побачивши навколо себе казку, дитина переживає хвилюючу радість. Їй хочеться донести свою думку до товаришів, виразити себе у слові» (Сухомлинський, 1976 , с. 512). Тож невипадково В. Сухомлинський у роботі 3 дітьми відводив важливе місце розвитку творчого самовираження, зокрема у словесній творчості, вважаючи творчість дітей глибоко своєрідною сферою їхнього духовного життя, самовираження та самоствердження, де яскраво виявляється індивідуальна самобутність кожної дитини, i iі неможливо охопити єдиними для всіх правилами» (Сухомлинський, 1977, c. 54).

Для розвитку і стимулювання творчої активності дітей в мовленнєвій діяльності необхідно створити відповідні ситуації, використовуючи стимуляційні прийоми, як-от: ситуації незавершеності або відкритості; вирішення великої кількості питань; мотивації у дітей відповідальності і незалежності; акцентування на дитячих самостійних розроблення, спостереженнях, узагальненнях; увага до інтересів дітей з боку дорослих та однолітків.

Суголосні 3 поглядами В. Сухомлинського у тому, що для формування багатого духовного світу дітей слід обирати такі способи й прийоми спонукання до їхньої активної діяльності, які розкривають перед вихованцями привабливу перспективу подолання труднощів, пробуджують такі емоції, як почуття гідності, честі, самоповаги (Сухомлинський, 1976, с. 222).

Провідними ознаками творчої діяльності дітей $\epsilon$ : особистісна характеристика; нетрадиційне, оригінальне мислення; нетрадиційний спосіб вирішення проблемних завдань; творчі можливості дитини; пошуково-перетворювальна активність. Зазначені характеристики творчої діяльності зароджуються на етапі дошкільного дитинства.

Ефективною формою розвитку творчого мовлення є складання казок, невеличких оповідань і розповідей. Це багатющий матеріал, який діти легко сприймають і швидко запам'ятовують. Викликані враження дають 


\section{Інноватика у вихованні. Випуск 14. 2021.}

можливість говорити, висловлювати свої думки, що й спонукає до розвитку творчого мовлення дітей (Березовська, 2004, с. 53).

У статті «Творчість у колективі. Роль казки в колективному житті дітей» В. Сухомлинський звертається до вихователів: «...якщо ви хочете, щоб вихованець ваш став розумним, допитливим, кмітливим, якщо у вас $\epsilon$ мета утвердити у його душі чутливість до найтонших відтінків думки й почуття інших людей, - виховуйте, пробуджуйте, одухотворюйте, надихайте його розум красою слова, думки, а краса рідного слова, його чарівна сила розкривається у казці» (Сухомлинський, 1976, с. 520).

Висновки і перспективи подальших розвідок. Отже, створюючи нові розповіді, казки, оповідання, розігруючи певні театральні ролі, дитина входить у світ прекрасної фантастичної дійсності, вчиться бути самостійною, чутливою до проблем інших, а також неповторною та оригінальною у своїх вчинках і діях. Творче мовлення стає засобом самовираження і самореалізації особистості дитини, дозволяє перетнути межу в розвитку творчої уяви, яка дає на все життя нове спрямування фантазії. Під його впливом розширюється творчий потенціал дитини, іiі творчі здібності.

Вважаємо, що самобутня, неперевершена педагогічна спадщина Василя Сухомлинського $є$ невичерпним джерелом творчого розвитку самих педагогів, учителів, вихователів, які здатні будуть виховати нове покоління молодих, творчих, національно спрямованих громадян України.

Перспективу подальших наукових досліджень вбачаємо у вивченні потреб, можливостей i засобів використання художніх творів В. Сухомлинського в роботі з дітьми дошкільного віку.

\section{СПИСОК ВИКОРИСТАНИХ ДЖЕРЕЛ}

Березовська, Л. (2004). Розвиток творчого мовленнєвого самовираження старших дошкільників в ігрових казкових ситуаџіях. Кандидат педагогічних наук. Одеса. 220 c.

Булаховсьский, Л. (1947). Виникнення i розвиток літературних мов. Мовознавство. T. IV-V. 136 с.

Гавриш, Н. (2001). Розвиток мовленнєвої творчості в дошкільному віці. Донецьк: ТОВ «Лебідь». 218 с.

Гончаренко, С. (1997). Український педагогічний словник. Київ : Либідь. 376с.

Гузій, Н. (2015). Педагогічний професіоналізм як наукова категорія. Педагогічна творчість, майстерність, професіоналізм у системі підготовки освітянських кадрів: здобутки, пошуки, перспективи : монографія. Київ : Вид-во НПУ імені М. П. Драгоманова. С. 104-151.

Моляко, В. (1985). Техническое творчество и трудовое воспитание. Москва: Знание. 134 с.

Сисоєва, С. (2006). Основи педагогічної творчості : Підручник. Київ: Міленіум. 344 с.

Сухомлинський, В. (1976). Вибрані твори : в 5-ти т. Т.1. Київ: Рад. школа. $654 \mathrm{c}$.

Сухомлинський, В. (1977). Вибрані твори : в 5 т. Т. 3 Київ : Рад. школа. 669 с.

Ямницький, В. (1993). Вплив емоціогенних ситуачій на творчу діяльність учнів. Кандидат психологічних наук. Одесса. 134 с. 


\section{Інноватика у вихованні. Випуск 14. 2021.}

Яременко, В., Сліпушко, О. (2006). Новий тлумачний словник украӥнськой мови: у 3 т. Київ: Аконіт. 941 с.

\section{REFERENCES}

Berezovska, L. (2004). Rozvytok tvorchoho movlennievoho samovyrazhennia starshykh doshkilnykiv $v$ ihrovykh kazkovykh sytuatsiiakh [Development of creative speech self-expression of senior preschoolers in game fairy-tale situations]. Kandydat pedahohichnykh nauk. Odesa. $220 \mathrm{~s}$. [in Ukrainian].

Bulakhovsskyi, L. (1947). Vynyknennia i rozvytok literaturnykh mov [Origin and development of literary languages]. Movoznavstvo. V. IV-V. 136 s. [in Ukrainian].

Havrysh, N. (2001). Rozvytok movlennievoi tvorchosti v doshkilnomu vitsi. [Development of speech creativity in preschool age] Donetsk: TOV "Lebid". 218 s. [in Ukrainian].

Honcharenko, S. (1997). Ukrainskyi pedahohichnyi slovnyk [Ukrainian pedagogical dictionary]. Kyiv : Lybid. 376 s. [in Ukrainian].

Huzii, N. (2015). Pedahohichnyi profesionalizm yak naukova katehoriia. Pedahohichna tvorchist, maisternist, profesionalizm u systemi pidhotovky osvitianskykh kadriv: zdobutky, poshuky, perspektyvy [Pedagogical professionalism as a scientific category. Pedagogical creativity, skill, professionalism in the system of educational training: achievements, searches, prospects]: monohrafiia. Kyiv: Vyd-vo NPU imeni M. P. Drahomanova. S. 104-151. [in Ukrainian].

Molyako, V. (1985). Tekhnicheskoye tvorchestvo $i$ trudovoye vospitaniye [Technical creativity and labor education]. Moskva: Znaniye. 134 s. [in Russian].

Sysoieva, S. (2006). Osnovy pedahohichnoi tvorchosti [Fundamentals of pedagogical creativity]: Pidruchnyk. Kyiv: Milenium. 344 s. [in Ukrainian].

Sukhomlynskyi, V. (1976). Vybrani tvory [Selected works]: v 5-ty t. T.1. Kyiv: Rad. shkola. 654 s. [in Ukrainian].

Sukhomlynskyi, V. (1977). Vybrani tvory [Selected works]: v 5 t. T. 3 Kyiv : Rad. shkola. 669 s. [in Ukrainian].

Yamnytskyi, V. (1993). Vplyv emotsiohennykh sytuatsii na tvorchu diialnist uchniv [The influence of emotional situations on the creative activity of students]. Kandydat psykholohichnykh nauk. Odessa. 134 s. [in Ukrainian].

Yaremenko, V., Slipushko, O. (2006). Novyi tlumachnyi slovnyk ukrainskoi movy: V. 3 [New explanatory dictionary of the Ukrainian language]. Kyiv: Akonit. 941 s. [in Ukrainian]. 


\title{
TEACHING CREATIVITY IN THE PEDAGOGICAL HERITAGE OF VASYL SUKHOMLYNSKY: DISCLOSURE OF CREATIVE POTENTIAL PERSONALITY OF THE CHILD
}

\author{
Liudmyla Berezovska \\ Doctor of Sciences (in Pedagogy), \\ Head at the Department of Theory \\ and Methods of Preschool Education at the State institution \\ "K. D. Ushynskyi South Ukrainian National Pedagogical University", \\ Odesa, Ukraine \\ ORCID: 0000-0002-3032-7261 \\ e-mail: lydunya@gmail.com
}

\begin{abstract}
The article analyzes the concept of "creativity"; Vasyl Sukhomlynskyi's views on the need to develop children's creative abilities by means of artistic words are analyzed. The peculiarities of V. Sukhomlynskyi's pedagogical activity, which are relevant and can be implemented in modern educational institutions, are considered. The peculiarity of the creative activity of educators of preschool institutions is the personal example of the teacher, the level of development of his creative activity, the ability to see and feel the beauty of the native language. The results of the study showed that educators do not pay due attention to the development of children's creative abilities, they themselves are insufficiently formed need and willingness to be creative in professional activities. A characteristic feature of pedagogical creativity is the co-creation between teacher and pupils, designed to stimulate the child's creative abilities, acquire knowledge and skills that create an original, individual product, rich in emotional thinking, creative idea, bright plot, specific word formation. To develop and stimulate children's creative activity in speech activity, it is necessary to create appropriate situations, using stimulating techniques, such as: situations of incompleteness or openness; solving a large number of issues; stimulating children's responsibility and independence; emphasis on children's independent developments, observations, generalizations; attention to the interests of children by adults and peers. An effective form of creative speech development is the compilation of stories, fairy tales, stories. Signs of creative activity are: unconventional, original thinking; atypical way of solving problem situations; creative abilities of the child. Creating new stories, fairy tales, stories, the child enters the world of fantastic reality, learns to feel the beauty of the native language, to be unique and original in their decisions.
\end{abstract}

Keywords: Vasyl Sukhomlynskyi, pedagogical heritage, creativity, formation of creative personality, preschool children, fairy tale.

Стаття надійшла до редакиії 24.09.2021 p. 